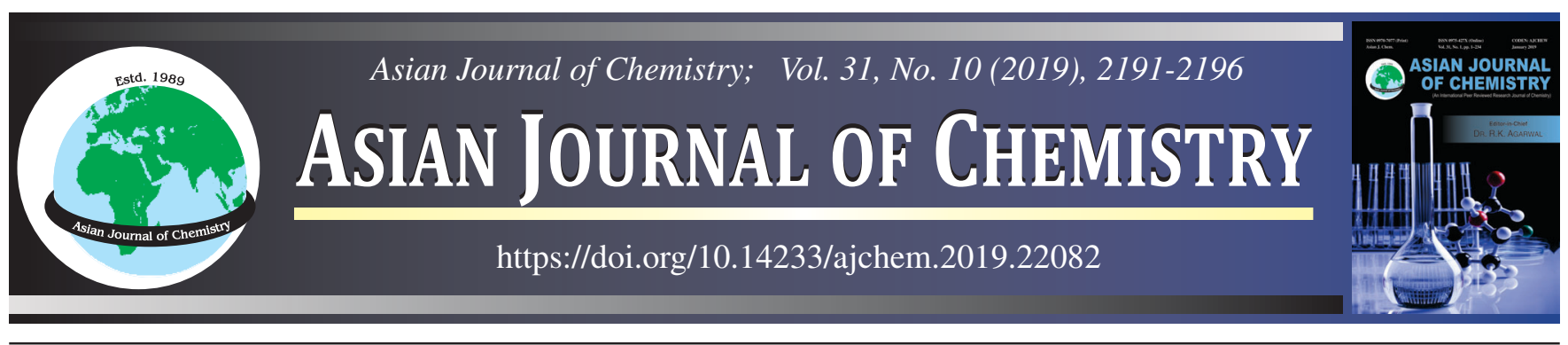

\title{
Synthesis and Characterization of 2-Pyrazoline Derivatives and their in silico and in vitro Studies on Antimicrobial and Anticancer Activities
}

\section{S. Rathinamanivannan ${ }^{1}, \mathrm{~K}_{\text {. }}$ Megha $^{2}$, Raja Chinnamanayakar ${ }^{2}$, Ashok Kumar $^{1}$ and M.R. Ezhilarasi ${ }^{1, *}$,}

${ }^{1}$ Department of Chemistry, Prist University, Thanjavur-613403, India

${ }^{2}$ Department of Chemistry, Karpagam Academy of Higher Education, Coimbatore-641021, India

*Corresponding author: E-mail: mrezhilarasi@gmail.com

Received: 15 March 2019; Accepted: 26 April 2019; Published online: 30 August 2019;

The new series of 1-(4,5-dihydro-5-phenyl-3-diphenylpyrazol-1-yl)butan-1-one derivatives were synthesized by cyclization method using biphenyl chalcone with $n$-butyric acid and hydrazine hydrate. The synthesized 1-(4,5-dihydro-5-phenyl-3-diphenylpyrazol-1-yl)butan-1one derivatives chemical structures were confirmed from spectral data such as FT-IR, ${ }^{1} \mathrm{H}$ and ${ }^{13} \mathrm{C}$ NMR. 2-Pyrazoline derivatives were docked with bacterial (1UAG) and breast cancer (1OQA) protein. Based on high binding affinity score, the best compound was subjected to in vitro anticancer activity by MTT assay. Also, antimicrobial activity were studied for synthesized 2-pyrazoline derivatives.

Keywords: Biphenyl chalcone, Hydrazine hydrate, $n$-Butyric acid, Antimicrobial activity, Molecular docking studies.

\section{INTRODUCTION}

Cancer is a life-threatening disease and the number of cancer-related deaths is increasing alarmingly. Based on the literature review, more than $90 \%$ of cancer patients die due to the chronic tumor metastases. The large number of anticancer drugs are currently available, but these drugs can eradicate cancer cells without harming normal tissues. So, the development of new chemotherapeutic scaffolds which selectively act on the target without any side effects has become an important objective of the medicinal fields [1]. In women community, breast cancer is the most important disease across world [2]. The pyrazole compounds exhibited a various biological activity such as anticancer [3-8], antibacterial [9] and fungi static activity [10].

The current research work is mainly focused on the synthesis of 2-pyrazoline derivatives (5a-e) from biphenyl chalcone react with hydrazine hydrate and $n$-butyric acid by cyclization method. Before that biphenyl chalcone derivatives were synthesized using various substituted aromatic aldehydes react with 4-acetylbiphenyl in the presence of strong base by ClaisenSchmidt condensation method. After that 2-pyrazoline compounds were docked with bacterial (1UAG) and breast cancer (1OQA) protein. Furthermore, based on high binding affinity score, that compound only was subjected to anticancer activity. Also, antimicrobial activity were screened for 2-pyrazoline derivatives.

\section{EXPERIMENTAL}

The chemicals were purchased from Sigma-Aldrich. Melting point were determine using MELT-Temp apparatus and the values were uncorrected. The FT-IR spectrum was recorded with the help of Shimadzu 8400s model and FT-IR spectrometer in the range of $4000-400 \mathrm{~cm}^{-1}$ and $\mathrm{KBr}$ used as internal reference. The Bruker $400 \mathrm{MHz}$ and $100 \mathrm{MHz}$ spectrometer was used to record the ${ }^{1} \mathrm{H}$ and ${ }^{13} \mathrm{C}$ NMR values.

Procedure for the synthesis of biphenyl chalcone derivatives (3a-e): 4-Acetyl biphenyl $(0.1 \mathrm{~mol})$ and substituted aromatic aldehyde $(0.1 \mathrm{~mol})$ were taken in $250 \mathrm{~mL}$ Erlenmeyer flask and to this approximately added nearly $30-35 \mathrm{~mL}$ of ethanol containing $20 \% \mathrm{NaOH}$ solution. This reaction mixture was stirred well for $3 \mathrm{~h}$ and then transferred the solution to 500 $\mathrm{mL}$ beaker containing pieces of ice cubes then kept in overnight at room temperature. After that solid precipitate was filtered and washed with water. This solid product was recrystallized using ethanol. Finally, the purity of the compound was checked by TLC [11].

This is an open access journal, and articles are distributed under the terms of the Attribution 4.0 International (CC BY 4.0) License. This license lets others distribute, remix, tweak, and build upon your work, even commercially, as long as they credit the author for the original creation. You must give appropriate credit, provide a link to the license, and indicate if changes were made. 
Synthesis of 1-(4,5-dihydro-5-phenyl-3-diphenylpyrazol1-yl)butan-1-one derivative (5a-e): Chalcone $(0.1 \mathrm{~mol})$ and hydrazine hydrate $(0.1 \mathrm{~mol})$ with $30 \mathrm{~mL}$ of $n$-butyric acid were taken in round bottom flask. This reaction mixture was refluxed for 14-16 h. Then the completion of the reaction was monitored using TLC. After completion of the reaction, this mixture was poured in to crushed ice cube containing $250 \mathrm{~mL}$ beaker and kept in overnight. Finally, the solid precipitate was filtered, washed with water. Then this solid product was recrystallized using ethanol. Finally, the purity of compound was checked by TLC (Scheme-I).
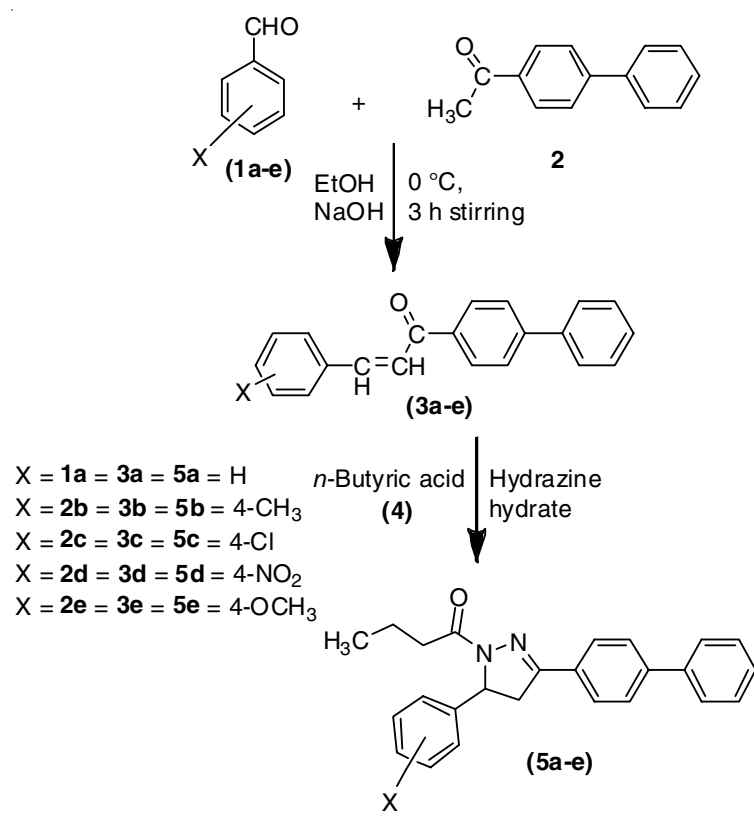

Scheme-I: Synthetic pathway for 2-pyrazoline derivatives (5a-e)

\section{Spectral data}

1-(4,5-Dihydro-3-diphenyl-5-phenylpyrazole-1-yl)butan-1-one derivative (5a): Yield $64 \%$; m.p.: $172^{\circ} \mathrm{C}$; Light brown; IR $\left(\mathrm{KBr}, v_{\max }, \mathrm{cm}^{-1}\right)$ : $1405.85(\mathrm{C}=\mathrm{N}), 1661.37(\mathrm{C}=\mathrm{O})$, 1156.52 (C-N), 3085.55 (Ar-CH); ${ }^{1} \mathrm{H}$ NMR $\left(\mathrm{CDCl}_{3}\right), 400 \mathrm{MHz}$; $\delta$ ppm: $3.18\left(1 \mathrm{H}, \mathrm{dd}, \mathrm{H} 4 \mathrm{a}, J_{4 \mathrm{a}, 4 \mathrm{e}}=17.6 \mathrm{~Hz}, J_{4 \mathrm{a}, 5 \mathrm{a}}=3.2 \mathrm{~Hz}\right) ; 3.76$ $\left(1 \mathrm{H}, \mathrm{dd}, \mathrm{H} 4 \mathrm{e}, J_{4 \mathrm{e}, 4 \mathrm{a}}=17 \mathrm{~Hz}, J_{4 \mathrm{ee}, 5 \mathrm{a}}=12.2 \mathrm{~Hz} ; 5.60(1 \mathrm{H}, \mathrm{dd}, \mathrm{H} 5 \mathrm{a}\right.$, $\left.J_{5 \mathrm{a}, 4 \mathrm{a}}=11.2 \mathrm{~Hz}, J_{5 \mathrm{a}, 4 \mathrm{e}}=3.2 \mathrm{~Hz}\right) ; 2.73-2.88\left(-\mathrm{CH}_{2^{-}}\right.$of $\left.\mathrm{C}-2^{\prime}\right)$, 1.66-1.77 (- $\mathrm{CH}_{2}-$ of C-3'); 7.23-7.82 (Ar-H). ${ }^{13} \mathrm{C}$ NMR $\delta$ ppm: $171.58(\mathrm{C}=0), 153.35(\mathrm{C}=\mathrm{N}), 36.22(\mathrm{C}-4), 60.14(\mathrm{C}-5), 18.47$ $\left(-\mathrm{CH}_{2}-\right), 29.76\left(-\mathrm{CH}_{2}-\right), 14.06\left(\mathrm{C}-4^{\prime}\right), 125.60-128.99$ (Ar-C), $142.97,142.14,140.18,130.46$ (Ipso carbon). Elemental analysis of $\mathrm{C}_{25} \mathrm{H}_{24} \mathrm{~N}_{2} \mathrm{O}$ calcd. (found) \%: C, 81.41 (81.49); $\mathrm{H}, 6.51$ (6.57); N, 7.59 (7.60); O, 4.34 (4.34).

1-(4,5-Dihydro-3-diphenyl-5-( -tolylpyrazole-1-yl) butan-1-one) derivative (5b): Yield $67 \%$; m.p.: $188^{\circ} \mathrm{C}$; light brown; IR $\left(\mathrm{KBr}, v_{\max }, \mathrm{cm}^{-1}\right)$ : $1402.25(\mathrm{C}=\mathrm{N}), 1664.57(\mathrm{C}=\mathrm{O})$, $1112.93(\mathrm{C}-\mathrm{N}), 3138.18$ (Ar-CH); ${ }^{1} \mathrm{H} \mathrm{NMR}\left(\mathrm{CDCl}_{3}\right), 400 \mathrm{MHz}$; $\delta$ ppm: $3.25\left(1 \mathrm{H}, \mathrm{d}, \mathrm{H} 4 \mathrm{a}, J_{4 \mathrm{a}, 4 \mathrm{e}}=16 \mathrm{~Hz}, J_{4 \mathrm{a}, 5 \mathrm{a}}=4 \mathrm{~Hz}\right) ; 3.88(1 \mathrm{H}$, dd, H4e, $\left.J_{4 \mathrm{e}, 4 \mathrm{a}}=18.1 \mathrm{~Hz}, J_{4 \mathrm{e}, 5 \mathrm{a}}=12.7 \mathrm{~Hz}\right) ; 5.69(1 \mathrm{H}, \mathrm{dd}, \mathrm{H} 5 \mathrm{a}$, $\left.J_{5 \mathrm{a}, 4 \mathrm{a}}=12.3 \mathrm{~Hz}, J_{5 \mathrm{a}, 4 \mathrm{e}}=3.6 \mathrm{~Hz}\right) ; 2.61-2.93\left(-\mathrm{CH}_{2}-\right.$ of C-2'), 1.53$1.69\left(-\mathrm{CH}_{2}-\right.$ of $\left.\mathrm{C}-3^{\prime}\right), 7.32-7.91(\mathrm{Ar}-\mathrm{H}) .{ }^{13} \mathrm{C}$ NMR $\delta \mathrm{ppm}$ : $171.02(\mathrm{C}=\mathrm{O}), 151.87(\mathrm{C}=\mathrm{N}), 37.13(\mathrm{C}-4), 57.83(\mathrm{C}-5), 19.60$ $\left(-\mathrm{CH}_{2}-\right), 32.08\left(-\mathrm{CH}_{2}-\right), 14.20\left(\mathrm{C}-4^{\prime}\right), 23.40\left(\mathrm{CH}_{3}\right), 127.73-$ 129.80 (Ar-C), 145.71, 144.52, 143.87, 143.21 (Ipso carbon).
Elemental analysis of $\mathrm{C}_{26} \mathrm{H}_{26} \mathrm{~N}_{2} \mathrm{O}$ calcd. (found) \%: $\mathrm{C}, 81.56$ (81.64); H, 6.79 (6.85); N, 7.32 (7.32); O, 4.18 (4.18).

1-(4,5-Dihydro-3-diphenyl-5-(4-chlorophenyl pyrazole1-yl)butan-1-one) derivative (5c): Yield $59 \%$; m.p.: $194^{\circ} \mathrm{C}$; light brown; IR $\left(\mathrm{KBr}, \mathrm{v}_{\max }, \mathrm{cm}^{-1}\right)$ : $1402.25(\mathrm{C}=\mathrm{N}), 1664.57$ $(\mathrm{C}=\mathrm{O}), 112.93(\mathrm{C}-\mathrm{N}), 3165.19(\mathrm{Ar}-\mathrm{CH}) ;{ }^{1} \mathrm{H} \mathrm{NMR}\left(\mathrm{CDCl}_{3}\right)$, $400 \mathrm{MHz} ; \delta$ ppm: $3.28\left(1 \mathrm{H}, \mathrm{dd}, \mathrm{H} 4 \mathrm{a}, J_{4 \mathrm{a}, 4 \mathrm{e}}=18.2 \mathrm{~Hz}, J_{4 \mathrm{a}, 5 \mathrm{a}}=\right.$ $3.8 \mathrm{~Hz}) ; 3.93\left(1 \mathrm{H}, \mathrm{dd}, \mathrm{H} 4 \mathrm{e}, J_{4 \mathrm{e}, 4 \mathrm{a}}=17.9 \mathrm{~Hz}, J_{4 \mathrm{e}, 5 \mathrm{a}}=11 \mathrm{~Hz}\right)$; $5.63\left(1 \mathrm{H}, \mathrm{dd}, \mathrm{H} 5 \mathrm{a}, J_{5 \mathrm{a}, 4 \mathrm{a}}=12.1 \mathrm{~Hz}, J_{5 \mathrm{a}, 4 \mathrm{e}}=4.1 \mathrm{~Hz}\right) ; 2.79-2.85$ $\left(-\mathrm{CH}_{2}-\right.$ of C-2');1.61-1.83 (- $\mathrm{CH}_{2}-$ of C-3'); 7.09-7.79 (Ar-H). ${ }^{13} \mathrm{C}$ NMR $\delta$ ppm: $171.93(\mathrm{C}=\mathrm{O}), 151.18(\mathrm{C}=\mathrm{N}), 37.61(\mathrm{C}-4)$, $59.03(\mathrm{C}-5), 18.99\left(-\mathrm{CH}_{2}-\right), 31.01\left(-\mathrm{CH}_{2^{-}}\right), 13.90\left(\mathrm{C}-4^{\prime}\right), 127.63-$ 130.31 (Ar-C); 141.06, 138.30, 138.01, 137.48 (Ipso carbon). Elemental analysis of $\mathrm{C}_{25} \mathrm{H}_{23} \mathrm{~N}_{2} \mathrm{OCl}$ calcd. (found) \%: $\mathrm{C}, 74.45$ (74.52); H, 5.70 (5.75); N, 6.94 (6.95); O, 3.97 (3.97); Cl, $8.79(8.80)$.

1-(4, 5-Dihydro-3-diphenyl-5-(4-nitrophenyl pyrazole1-yl)butan-1-one) derivative (5d): Yield $67 \%$; m.p.: $208^{\circ} \mathrm{C}$; light brown; IR ( $\left.\mathrm{KBr}, v_{\max }, \mathrm{cm}^{-1}\right)$ : $1402.25(\mathrm{C}=\mathrm{N}), 1656.85$ $(\mathrm{C}=\mathrm{O}), 1115.81(\mathrm{C}-\mathrm{N}), 3165.19(\mathrm{Ar}-\mathrm{CH}) ;{ }^{1} \mathrm{H} \mathrm{NMR}\left(\mathrm{CDCl}_{3}\right)$, $400 \mathrm{MHz} ; \delta$ ppm: $3.31\left(1 \mathrm{H}, \mathrm{dd}, \mathrm{H} 4 \mathrm{a}, J_{4 \mathrm{a}, 4 \mathrm{e}}=17.6 \mathrm{~Hz}, J_{4 \mathrm{a}, 5 \mathrm{a}}=\right.$ $4.3 \mathrm{~Hz}) ; 3.79\left(1 \mathrm{H}, \mathrm{dd}, \mathrm{H} 4 \mathrm{e}, J_{4 \mathrm{e}, 4 \mathrm{a}}=18.3 \mathrm{~Hz}, J_{4 \mathrm{e}, 5 \mathrm{a}}=12.7 \mathrm{~Hz}\right)$; $5.71\left(1 \mathrm{H}, \mathrm{dd}, \mathrm{H} 5 \mathrm{a}, J_{5 \mathrm{a}, 4 \mathrm{a}}=12.9 \mathrm{~Hz}, J_{5 \mathrm{a}, 4 \mathrm{e}}=4.4 \mathrm{~Hz}\right) ; 2.63-2.77$ (- $\mathrm{CH}_{2}$ of C-2'); 1.58-1.71 (- $\mathrm{CH}_{2}-$ of C-3'); 7.13-7.89 (Ar-H). ${ }^{13} \mathrm{C}$ NMR $\delta$ ppm: $170.08(\mathrm{C}=\mathrm{O}), 150.08(\mathrm{C}=\mathrm{N}), 35.39(\mathrm{C}-4)$, $58.92(\mathrm{C}-5), 18.10\left(-\mathrm{CH}_{2}{ }^{-}\right), 29.03\left(-\mathrm{CH}_{2}-\right), 14.99\left(\mathrm{C}-4^{\prime}\right), 128.03-$ 131.91 (Ar-C), 143.76, 139.94, 138.89, 137.35 (Ipso carbon). Elemental analysis of $\mathrm{C}_{25} \mathrm{H}_{23} \mathrm{~N}_{3} \mathrm{O}_{3}$ calcd. (found) \%: $\mathrm{C}, 72.55$ (72.62); H, 5.56 (5.61); N, 10.15 (10.16); O, 11.60 (11.61).

1-(4,5-Dihydro-3-diphenyl-5-(4-methoxyphenyl pyrazole-1-yl)butan-1-one) derivative (5e): Yield $67 \%$; m.p.: 196 ${ }^{\circ} \mathrm{C}$; light brown; IR $\left(\mathrm{KBr}, \mathrm{v}_{\max }, \mathrm{cm}^{-1}\right): 1412.25(\mathrm{C}=\mathrm{N}), 1664.57$ $(\mathrm{C}=\mathrm{O}), 1246.02(\mathrm{C}-\mathrm{N}), 3165.19(\mathrm{Ar}-\mathrm{CH}) ;{ }^{1} \mathrm{H} \mathrm{NMR}\left(\mathrm{CDCl}_{3}\right)$, $400 \mathrm{MHz} ; \delta$ ppm: $3.28\left(1 \mathrm{H}, \mathrm{dd}, \mathrm{H} 4 \mathrm{a}, J_{4 \mathrm{a}, 4 \mathrm{e}}=16.9 \mathrm{~Hz}, J_{4 \mathrm{a}, 5 \mathrm{a}}=\right.$ $3.7 \mathrm{~Hz}) ; 3.82\left(1 \mathrm{H}, \mathrm{dd}, \mathrm{H} 4 \mathrm{e}, J_{4 \mathrm{e}, 4 \mathrm{a}}=17.7 \mathrm{~Hz}, J_{4 \mathrm{e}, 5 \mathrm{a}}=12.3 \mathrm{~Hz}\right)$; $5.65\left(1 \mathrm{H}, \mathrm{dd}, \mathrm{H} 5 \mathrm{a}, J_{5 \mathrm{a}, 4 \mathrm{a}}=12.4 \mathrm{~Hz}, J_{5 \mathrm{a}, 4 \mathrm{e}}=4 \mathrm{~Hz}\right) ; 2.69-2.78\left(-\mathrm{CH}_{2^{-}}\right.$ of C-2'); 1.63-1.80 (- $\mathrm{CH}_{2}-$ of C-3'); $3.73\left(-\mathrm{OCH}_{3}\right), 7.39-7.97$ $(\mathrm{Ar}-\mathrm{H}) .{ }^{13} \mathrm{C}$ NMR $\delta$ ppm: $172.33(\mathrm{C}=\mathrm{O}), 152.99(\mathrm{C}=\mathrm{N}), 36.01$ (C-4), 57.19 (C-5), $19.07\left(-\mathrm{CH}_{2}-\right), 30.91\left(-\mathrm{CH}_{2}{ }^{-}\right), 13.95\left(\mathrm{C}-4^{\prime}\right)$, $55.98\left(\mathrm{OCH}_{3}\right), 126.03-132.92$ (Ar-C), 144.01, 140.01, 140.09, 139.82 (Ipso carbon). Elemental analysis of $\mathrm{C}_{26} \mathrm{H}_{26} \mathrm{~N}_{2} \mathrm{O}_{2}$ calcd. (found) \%: C, 78.29 (78.36); H, 6.52 (6.58); N, 7.02 (7.03); $\mathrm{O}, 8.03$ (8.03).

Molecular docking studies: The docking studies have been carried out using ADT version 1.5.6 and Auto dock version 4.2.5.1 docking program.

Preparation of protein: The bacterial protein and human breast cancer protein were directly downloaded from PDB (Protein Data Bank) with pdb id: 1UAG and 1OQA.

Ligand preparation: 2D structure of 2-pyrazoline derivatives is drawn using Chemdraw ultra 8.0. After that Chem 3D ultra 8.0 was used to convert the 2D structure into $3 \mathrm{D}$ structure. The energy is minimized using semi empirical AM1 method. All the structures are saved as pdb file format for input to ADT. Finally, all the ligand structures are saved as Pdb format to carry out docking study in Auto dock Vina.

Formation of grid: A grid box with a dimension of $40 \times$ $40 \times 40 \AA^{3}$ in $0.375 \AA$ spacing and centered on $30.473,47.997$, 
9.563 has created around the binding site of protein using ADT. The center of the box was set at ligand center and grid energy calculations were carried out.

Docking protocol: The Auto dock calculation such as default parameters had been used and 10 docked confirmations were generated for each compound. The energy calculations was done using genetic algorithms. The outputs were exported to chimera 1.10 and discovery studio 4.5 for visual inspection of the binding modes and interaction of the compounds with amino acid residues in the active site [12].

Antimicrobial activity: 2-Pyrazoline compounds were screened for antimicrobial activity by agar disk diffusion method. In this studies, ciprofloxacin was used as a reference compound and dimethyl sulfoxide as the solvent control of this activity. Four different strains viz. Streptococcus, Staphylococcus aureus, Escherichia coli and Pseudomonas aeruginosa were used.

\section{Anticancer activity}

MTT assay: MDA-MB-231 Cell was initially procured from National Centre for Cell Sciences (NCCA), Pune, India and maintained Dulbecco's modified eagle's medium, DMEM (Sigma Aldrich, USA). The cell line was cultured in $25 \mathrm{~cm}^{2}$ tissue culture flask with DMEM supplemented with $10 \%$ FBS, L-glutamine, sodium bicarbonate (Merck, Germany) and an antibiotic solution containing penicillin $(100 \mathrm{U} / \mathrm{mL})$. Streptomycin $(100 \mu \mathrm{g} / \mathrm{mL})$ and ampheotericin B $(2.5 \mu \mathrm{g} / \mathrm{mL})$ cultured cell lines were kept at $37{ }^{\circ} \mathrm{C}$ in a humidified $5 \% \mathrm{CO}_{2}$ incubator (NBS Eppendorf, Germany). The viability of cells was evaluated by direct observation of cells by inverted phase contrast microscope and followed by MTT assay method.

Cells seeding in 96 well plate: Two-day old confluent monolayer of cells try ionized and the cells were suspended in $10 \%$ growth medium, $100 \mu \mathrm{L}$ cell suspension $\left(5 \times 10^{4}\right.$ cells/ well) was seeded in 96 well tissue culture plate and incubated at $37^{\circ} \mathrm{C}$ in a humidified $5 \% \mathrm{CO}_{2}$ incubator.

Preparation of compound stock: $1 \mathrm{mg}$ of a sample was weighed and dissolved in $1 \mathrm{~mL}$ DMEM using a cyclomixer. The sample solution was filtered through $0.22 \mu \mathrm{m}$ Millipore syringe filter to ensure the sterility.

Anticancer evaluation: After $24 \mathrm{~h}$ the growth medium was removed, freshly prepared each compounds in $5 \%$ DMEM was five times serially diluted by two-fold dilution $(100,50$, $25,12.5,6.25 \mu \mathrm{g} / \mathrm{mL}$ ) in $500 \mu \mathrm{L}$ of $5 \%$ DMEM and ach concentration of $100 \mu \mathrm{L}$ were added in triplicates to the respective wells and incubated at $37^{\circ} \mathrm{C}$ in a humidified $5 \% \mathrm{CO}_{2}$ incubator. Non-treated control cells were also maintained.

Anticancer assay by MTT method: $15 \mathrm{mg}$ of MTT (Sigma, M-5655) was reconstituted in $3 \mathrm{~mL}$ PBS until completely dissolved and sterilized by filter sterilization. After $24 \mathrm{~h}$ of the incubation period, the sample content in wells was removed and $30 \mu \mathrm{L}$ of reconstituted MTT solution was added to all test and cell control wells, the plate was gently shaken well and incubated at $37^{\circ} \mathrm{C}$ in a humidified $5 \% \mathrm{CO}_{2}$ incubator for $4 \mathrm{~h}$. After the incubation period, the supernatant was removed and $100 \mu \mathrm{L}$ of MTT solubilisation solution (DMSO, Sigma- Aldrich) was added and the wells were mixed gently in order to solubilize the formazan crystals. The absorbance values were measured by using a microplate reader at a wavelength of $540 \mathrm{~nm}$ [13].

The $\%$ of growth inhibition was calculated using the formula:

$$
\text { Viability }(\%)=\frac{\text { Mean OD sample }}{\text { Mean OD of control group }} \times 100
$$

\section{RESULTS AND DISCUSSION}

Biphenyl chalcone derivatives (3a-e) were synthesized from 4-acetylbiphenyl reacts with aromatic substituted aldehydes in the presence of strong base by Claisen-Schmidt condensation method. Then biphenyl chalcone derivatives were reacted with hydrazine hydrate and $n$-butyric acid by cyclization method to yield 2-pyrazoline derivatives (Scheme-I). The synthesized 2-pyrazolines chemical structure were elucidated using FT-IR, ${ }^{1} \mathrm{H}$ and ${ }^{13} \mathrm{C}$ NMR spectral studies.

In the FT-IR spectrum of compound $\mathbf{5 a}$, the $\mathrm{C}=\mathrm{N}$ stretching frequency of pyrazole moiety observed at $1405.85 \mathrm{~cm}^{-1}$ and the $\mathrm{C}=\mathrm{O}$ stretching was observed at $1661.37 \mathrm{~cm}^{-1}$, while the C-N stretching observed at $1156.52 \mathrm{~cm}^{-1}$. The aromatic $\mathrm{CH}$ stretching was observed at $3085.55 \mathrm{~cm}^{-1}$. In ${ }^{1} \mathrm{H}$ NMR spectrum compound 5a exhibited the doublet of doublet at $3.18 \mathrm{ppm}$ $J_{4 a, 4 e}=17.6 \mathrm{~Hz}$ and $J_{4 a, 5 \mathrm{a}}=3.2 \mathrm{~Hz}$ is due to the presence of $\mathrm{H}$ 4a proton of pyrazole moiety. Also H-4e proton of pyrazole moiety exhibited another doublet of doublet at $3.76 \mathrm{ppm} J_{4 \mathrm{e}, 5 \mathrm{a}}$ $=17 \mathrm{~Hz}$ and $J_{4 \mathrm{e}, 5 \mathrm{a}}=12.2 \mathrm{~Hz}$. Doublet of doublet at $5.60 \mathrm{ppm}$ $J_{5 \mathrm{a}, 4 \mathrm{a}}=11.2 \mathrm{~Hz} \& J_{5 \mathrm{a}, 4 \mathrm{e}}=3.2 \mathrm{~Hz}$ which indicate the presence of $\mathrm{H}-5 \mathrm{a}$ proton of pyrazole moiety. The multiplet present at 2.73$2.88 \mathrm{ppm}$ is due to the presence of $-\mathrm{CH}_{2}$ - of butane moiety. The multiplet present at $1.66-1.77 \mathrm{ppm}$ is due to the presence of methyl group in butane moiety. The aromatic protons are appeared at 7.23-7.82 $\mathrm{ppm}$.

In ${ }^{13} \mathrm{C}$ NMR spectrum, compound $\mathbf{5 a}$ shows the ${ }^{13} \mathrm{C}$ NMR at $171.58 \mathrm{ppm}$ which is attributed to $\mathrm{C}=\mathrm{O}$. The ${ }^{13} \mathrm{C}$ NMR at $153.35 \mathrm{ppm}$ is due to the presence of $\mathrm{C}-3$ carbon of pyrazole moiety and at $36.22 \mathrm{ppm}$ is due to the presence of C-4 carbon of pyrazole moiety. Similarly, at $60.14 \mathrm{ppm}$ is due to the presence of C-5 carbon of pyrazole moiety and at $14.06 \mathrm{ppm}$ is due to the presence of methyl group of butane moiety. However, ${ }^{13} \mathrm{C}$ resonance at $18.47 \mathrm{ppm}$ is due to the presence of $\mathrm{C}-3^{\prime}$ carbon of $-\mathrm{CH}_{2}$ - group of butane moiety and at $29.76 \mathrm{ppm}$ is due to the presence of $\mathrm{C}-2^{\prime}$ carbon of $-\mathrm{CH}_{2}$-group of butane moiety. The aromatic carbons are appeared at 125.60-128.99 ppm.

in silico Activity: The synthesized 2-pyrazoline derivatives were docked with bacterial protein (PDB id: 1UAG) and breast cancer protein (PDB id: 1OQA). The docking studies which are reported in terms of the docking score, which means the lower score, the better and interactions. In ligand, 2-pyrazoline derivatives (5a-e) were individually, docked with bacterial proteins. Docking results are shown in Table-1. Thus, it can be seen that 2-pyrazoline derivatives exhibit good docking score compared to the standard drug (ciprofloxacin). Based on the docking score, compound $\mathbf{5} \mathbf{c}$ exhibit high binding affinity score compared with other compound of this series. Compound $\mathbf{5 c}$ exhibit two H-bond interaction with the amino residue is SER A: 415 and PHE A: 422. Also, this compound exhibited two hydrophobic interaction with the amino residue is ALA A: 414 and LEU A: 416. Other compounds results are also shown in Table-1.

2-Pyrazoline derivatives were docked with breast cancer protein 1OQA: The synthesized 2-pyrazoline compounds were docked with breast cancer protein. The binding affinity 


\begin{tabular}{|c|c|c|c|}
\hline \multicolumn{4}{|c|}{$\begin{array}{c}\text { TABLE-1 } \\
\text { 2-PYRAZOLINE COMPOUNDS WERE DOCKED } \\
\text { WITH BACTERIAL PROTEIN 1UAG }\end{array}$} \\
\hline Compound & $\begin{array}{c}\text { Binding } \\
\text { affinity score } \\
(\mathrm{kcal} / \mathrm{mol})\end{array}$ & $\begin{array}{l}\text { H-Bond } \\
\text { interaction }\end{array}$ & $\begin{array}{l}\text { Hydrophobic } \\
\text { interaction }\end{array}$ \\
\hline \multirow{2}{*}{$5 a$} & \multirow{2}{*}{-8.4} & SER A:415 & ALA A:414 \\
\hline & & PHE A:422 & LEU A:416 \\
\hline \multirow{2}{*}{$5 \mathbf{b}$} & \multirow{2}{*}{-8.4} & SER A:415 & ALA A:414 \\
\hline & & PHE A:422 & LEU A:416 \\
\hline \multirow{2}{*}{$5 c$} & \multirow{2}{*}{-8.5} & SER A:415 & ALA A:414 \\
\hline & & PHE A:422 & LEU A:416 \\
\hline \multirow{2}{*}{$5 d$} & \multirow{2}{*}{-8.3} & SER A:415 & ALA A:414 \\
\hline & & PHE A:422 & LEU A:416 \\
\hline \multirow{2}{*}{$5 e$} & \multirow{2}{*}{-8.3} & SER A:415 & ALA A:414 \\
\hline & & PHE A:422 & LEU A:416 \\
\hline Ciprofloxacin & -7.7 & $\begin{array}{l}\text { ASN A:178, } \\
\text { ASN A:271, } \\
\text { GLU A:327 }\end{array}$ & ALA A:328 \\
\hline
\end{tabular}

\begin{tabular}{cccl}
\multicolumn{5}{c}{ TABLE 2 } \\
\multicolumn{5}{c}{$\begin{array}{c}\text { 2-PYRAZOLINEDERIVATIVES WERE DOCKED } \\
\text { WITH BREAST CANCER PROTEIN }\end{array}$} \\
\hline Compd. & $\begin{array}{c}\text { Binding affinity } \\
\text { score }(\mathrm{kcal} / \mathrm{mol})\end{array}$ & $\begin{array}{c}\text { H-Bond } \\
\text { interaction }\end{array}$ & Hydrophobic interaction \\
\hline $\mathbf{5 a}$ & -6.8 & HIS A: 69 & PRO A: 59, PRO A: 103, \\
& & & ILE A: 102 \\
5b & -7.1 & - & PRO A: 18, CYS A: 15, \\
& & & VAL A: 38 \\
5c & -7.1 & - & PRO A: 18, VAL A: 38, \\
& & - & CYS A: 15 \\
5d & -7.2 & - & CYS A: 15 \\
5e & -7.0 & & \\
\hline
\end{tabular}

score, hydrogen bond interaction and hydrophobic interaction results are shown in Table-2. From this result, compound 5d have high binding affinity score $(-7.2 \mathrm{kcal} / \mathrm{mol})$ compared with

the other compound of this series. Compound $\mathbf{5 d}$ does not exhibit any $\mathrm{H}$-bond interaction with amino residue of protein 1OQA. Also, this compound exhibit only one hydrophobic interaction with the amino residue is CYS A: 15 (Fig. 1). The 2D and 3D image of the synthesized 2-pyrazoline derivatives (5a-e) are shown in Table-3.

MTT assay for 1-(4,5-dihydro-3-diphenyl-5-(4-nitrophenylpyrazole-1-yl)butan-1-one (5d): Based on high binding

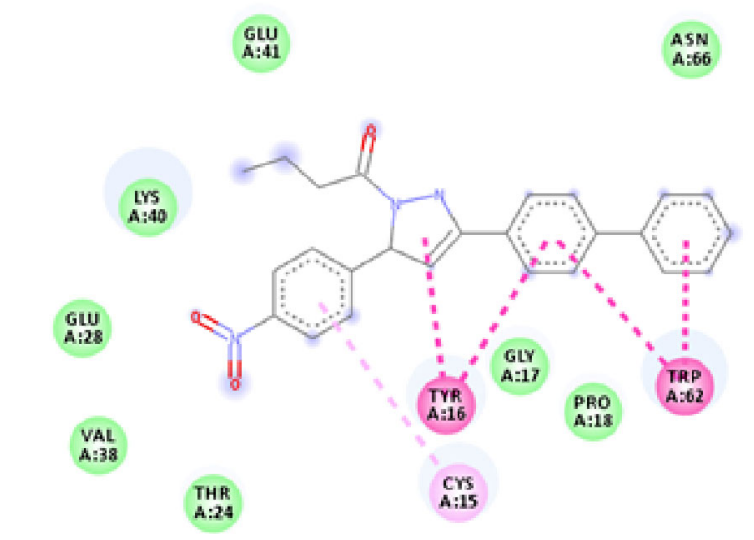

Interactions

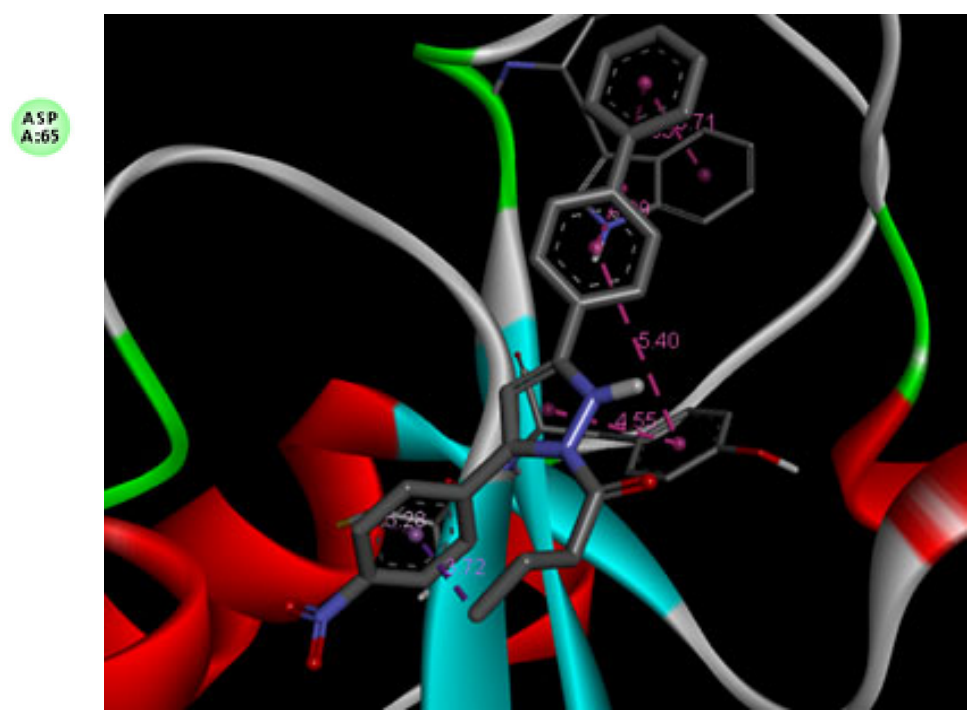

Fig. 1. 2D and 3D image for compound 5d docked with breast cancer protein 1OQA

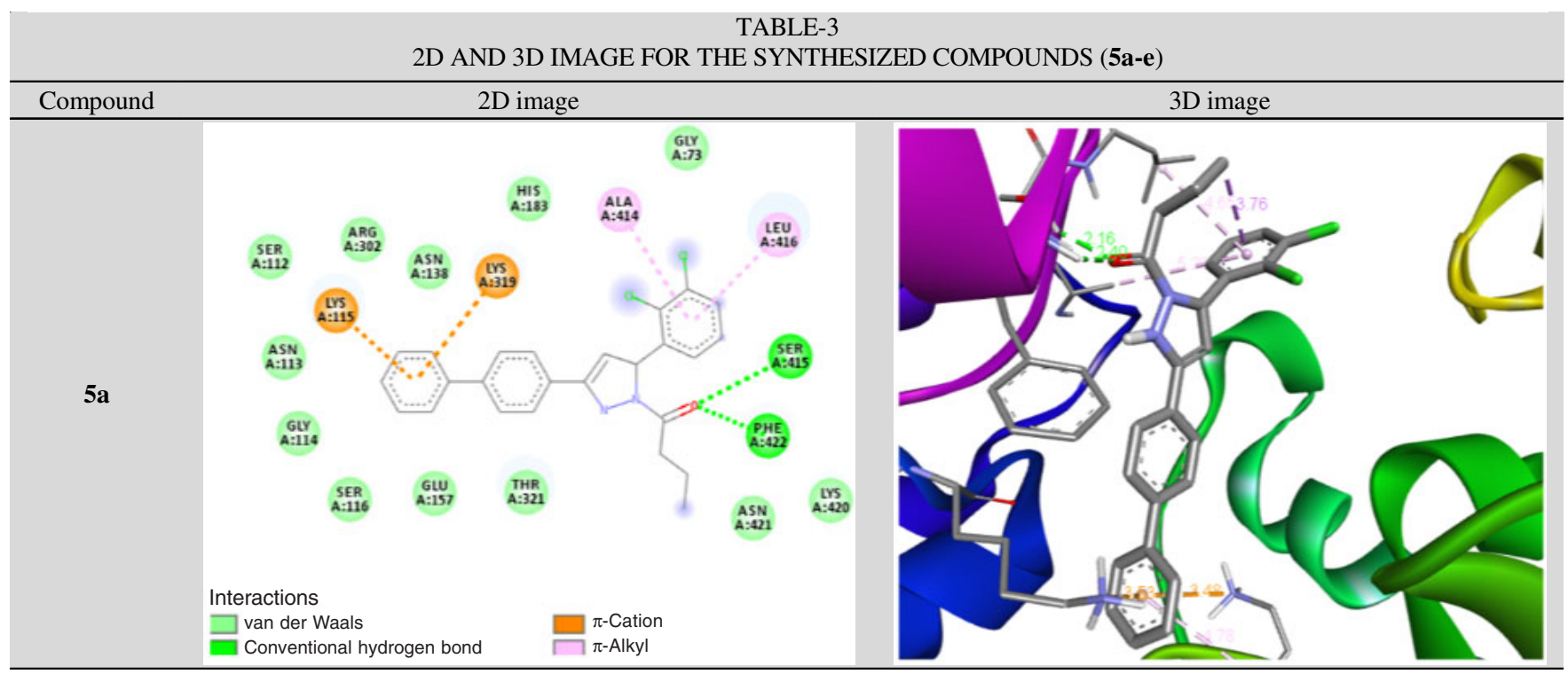




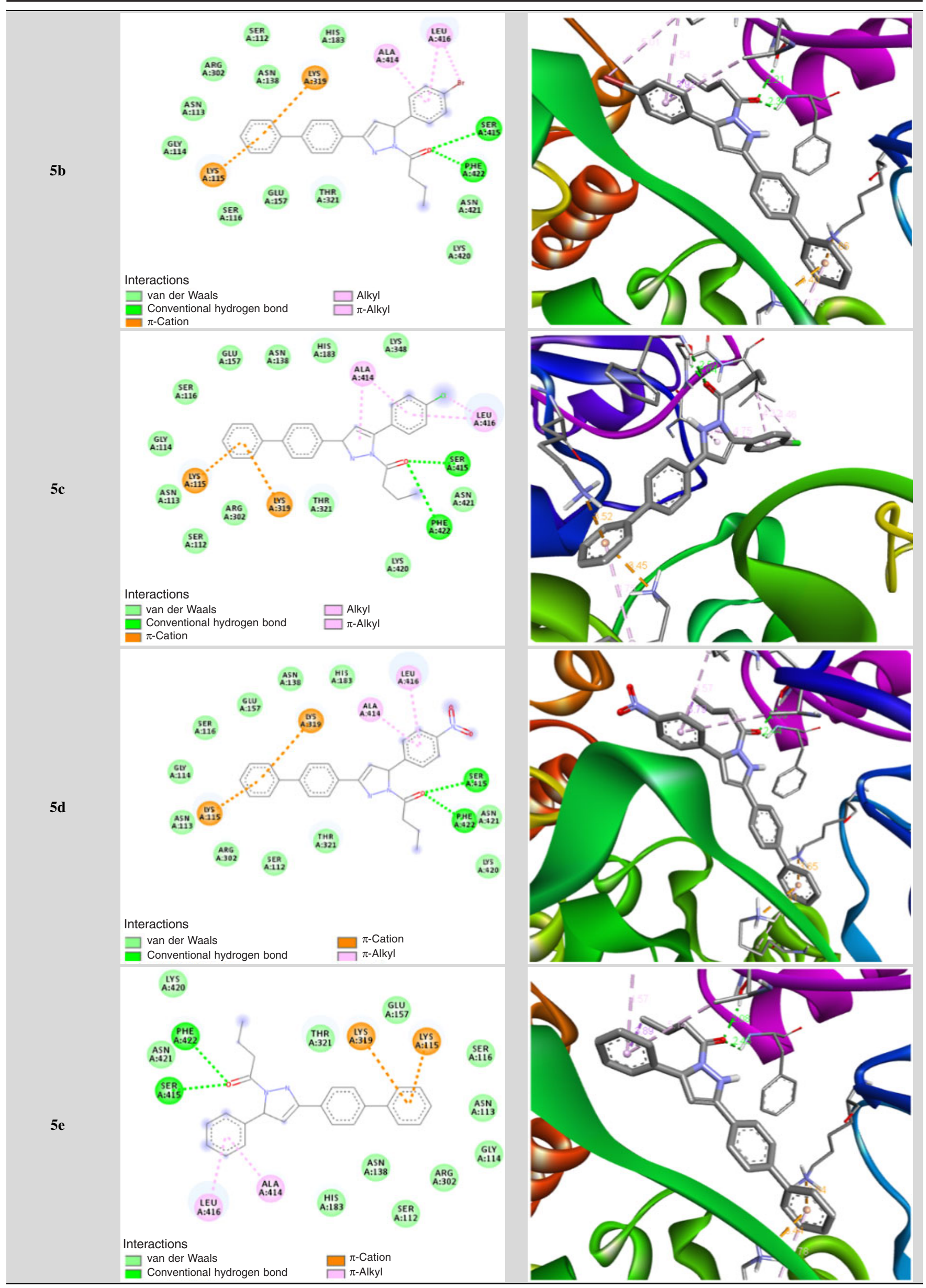




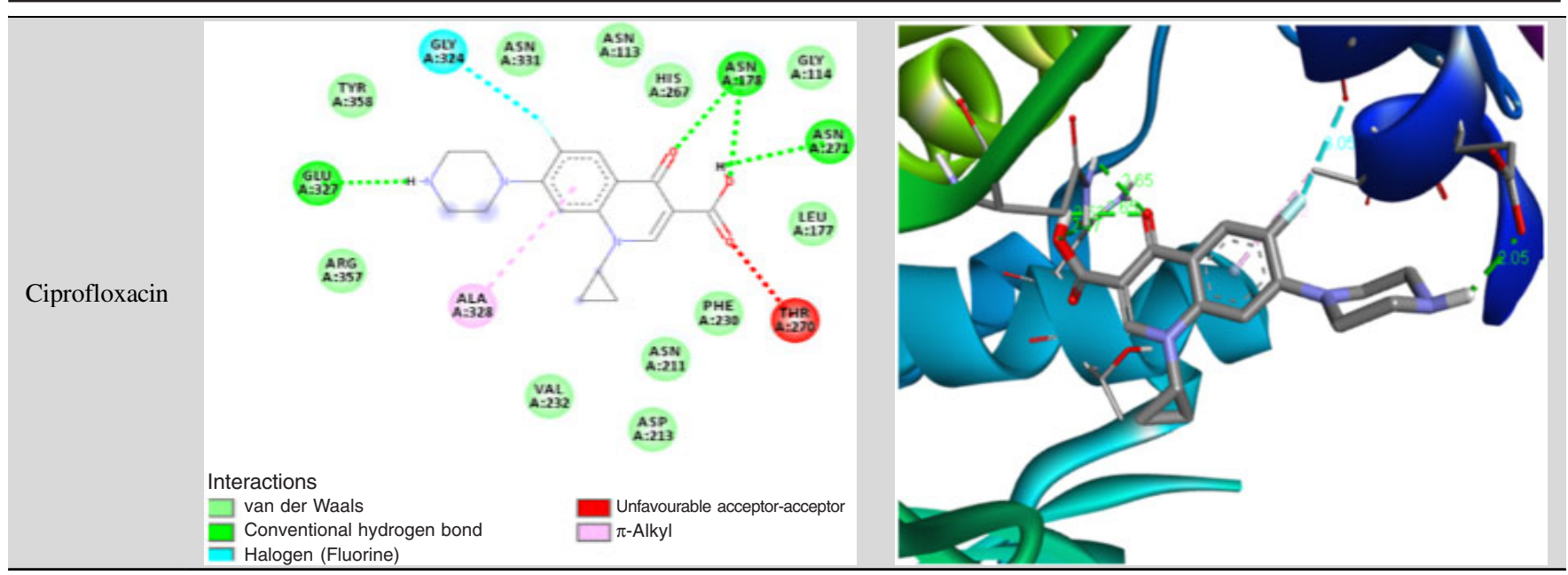

affinity score, synthesized compound $\mathbf{5 d}$ only was performed to anticancer activity using various concentration (100, 50, $25,12.5,6.25 \mu \mathrm{g} / \mathrm{mL}$ ). From this result, compound $\mathbf{5 d}$ exhibit good activity at low concentration $(6.25 \mu \mathrm{g} / \mathrm{mL})$ compared with other concentration. The $\mathrm{LC}_{50}$ value of this compound is $74.27 \mu \mathrm{g} / \mathrm{mL}$. The experiments were conducted in triplicate and the mean value was calculated.

Antimicrobial activity: 2-Pyrazoline derivatives were subjected to antimicrobial activity by agar disk diffusion method using only one concentration $(2.5 \mathrm{mg} / \mathrm{mL})$. Compounds $\mathbf{5 c}$ and $\mathbf{5 e}$ exhibited good zone of inhibition against Staphylococcus aureus while compound 5a exhibited good zone of inhibition against $S$. pyogenes and E. coli (Fig. 2). However, compound 5d exhibits good zone of inhibition against Pseudomonas sp. Thus, most of the pyrazoline derivatives exhibited better activity compared with standard drug.

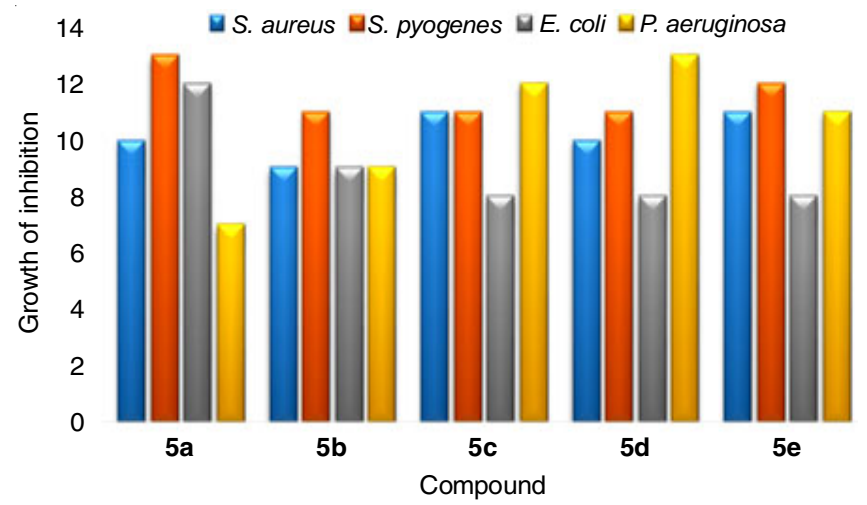

Fig. 2. Antibacterial activity with different strains for 2-pyrazoline derivatives $(\mathbf{5 a}-\mathbf{e})$

\section{Conclusion}

2-Pyrazoline derivatives were synthesized using biphenyl chalcone react with hydrazine hydrate and $n$-butyric acid by Michael addition method. The docking study was carried out for 2-pyrazoline derivatives using bacterial protein and breast cancer protein. The results showed that the receptor and the compound have greater potency of interactions in a binding site. Especially, compound 5d exhibited good binding score with the cancer protein. The $\mathrm{LC}_{50}$ value of compound $\mathbf{5 d}$ is found to be $74.27 \mu \mathrm{g} / \mathrm{mL}$. The antimicrobial activity results showed that 2-pyrazoline derivatives also exhibited good activity against the studied four strains.

\section{CONFLICT OF INTEREST}

The authors declare that there is no conflict of interests regarding the publication of this article.

\section{REFERENCES}

1. S.S. Abd El-Karim, M.M. Anwar, N.A. Mohamed, T. Nasr and S.A. Elseginy, Bioorg. Chem., 63, 1 (2015); https://doi.org/10.1016/j.bioorg.2015.08.006.

2. Y.-C. Jung, S. Han, L. Hua, Y.-H. Ahn, H. Cho, C.-J. Lee, H. Lee, Y.-Y. Cho, J.-H. Ryu, R. Jeon and W.-Y. Kim, Biochem. Biophys. Res. Commun., 470, 294 (2016); https://doi.org/10.1016/i.bbrc.2016.01.066

3. A. Abdel-Aziz, H.S.A. El-Zahabi and K.M. Dawood, Eur. J. Med. Chem., 45, 2427 (2010);

https://doi.org/10.1016/j.ejmech.2010.02.026.

4. R. Dayam, F. Aiello, J. Deng, Y. Wu, A. Garofalo, X. Chen and N. Neamati, J. Med. Chem., 49, 4526 (2006); https://doi.org/10.1021/jm051296s.

5. Y.R. Liu, J.-Z. Luo, P.-P. Duan, J. Shao, B.-X. Zhao and J.-Y. Miao, Bioorg. Med. Chem. Lett., 22, 6882 (2012); https://doi.org/10.1016/j.bmcl.2012.09.032.

6. I. Vujasinovic, A. Paravic-Radièevic, K. Mlinaric-Majerski, K. Brajsa and B. Bertosa, Bioorg. Med. Chem., 20, 2101 (2012); https://doi.org/10.1016/j.bmc.2012.01.032.

7. A.M. Farag, K.A.K. Ali, T.M.A. El-Debss, A.S. Mayhoub, A.-G.E. Amr, N.A. Abdel-Hafez and M.M. Abdulla, Eur. J. Med. Chem., 45, 5887 (2010); https://doi.org/10.1016/j.ejmech.2010.09.054.

8. A.M. Farag, A.S. Mayhoub, T.M.A. Eldebss, A.-G.E. Amr, K.A.K. Ali, N.A. Abdel-Hafez and M.M. Abdulla, Arch. Pharm. Chem. Life Sci., 343, 384 (2010); https://doi.org/10.1002/ardp.200900176.

9. H.A. Abdel-Aziz, A.A.I. Mekawey and K.M. Dawood, Eur. J. Chem., 44, 3637 (2009); https://doi.org/10.1016/j.ejmech.2009.02.020.

10. R. Sridhar, P.T. Perumal, S. Etti, G. Shanmugam, M.N. Ponnuswamy, V.R. Prabavathy and N. Mathivanan, Bioorg. Med. Chem. Lett., 14, 6035 (2004); https://doi.org/10.1016/j.bmcl.2004.09.066.

11. R. Chinnamanayakar, M.R. Ezhilarasi, B. Prabha and Kulandhaivel, Asian J. Chem., 30, 783 (2018);

https://doi.org/10.14233/ajchem.2018.20992.

12. R. Sri Dharani, R. Ranjitha, R. Sripathi, K.S. Ali Muhammad and S. Ravi, Asian J. Pharm. Clin. Res., 9, 121 (2016); https://doi.org/10.22159/ajpcr.2016.v9i5.12693.

13. L.B. Talarico, R.G.M. Zibetti, P.C.S. Faria, L.A. Scolaro, M.E.R. Duarte, M.D. Noseda, C.A. Pujol and E.B. Damonte, Int. J. Biol. Macromol., 34, 63 (2004);

https://doi.org/10.1016/j.ijbiomac.2004.03.002. 